\title{
Perbedaan Intensitas Penyengatan Meningeal Hasil MRI antara Sekuens T2 FLAIR Post Contrast dan T1WI Post Contrast Gadolinium-DTPA dalam Mendeteksi Penyangatan Meningeal pada Kasus Meningitis Tuberkulosis
}

\author{
Arie Hendarin, ${ }^{1}$ Rista D. Soetikno, ${ }^{2}$ Harry Galuh Nugraha ${ }^{2}$ \\ ${ }^{1}$ Rumah Sakit Umum Daerah Kabupaten Sumedang, ${ }^{2}$ Departemen Radiologi Fakultas Kedokteran \\ Universitas Padjadjaran/Rumah Sakit Umum Pusat Dr. Hasan Sadikin Bandung
}

\begin{abstract}
Abstrak
Diagnosis meningitis TB terutama pada kasus possible dan probable sulit ditegakkan. Pemeriksaan MRI kepala dengan kontras Gadolinium-DTPA adalah modalitas radiologi yang paling sensitif untuk membantu mendiagnosis penyakit ini. Penyangatan meningeal di daerah basal merupakan gambaran MRI yang paling banyak ditemukan pada meningitis TB. Tujuan penelitian ini adalah mengetahui perbedaan peningkatan intensitas sinyal meningen sekuens T2-FLAIR dengan T1WI pada pasien meningitis tuberkulosis menggunakan pemeriksaan MRI kepala dengan kontras Gadolinium-DTPA di RSUP Dr. Hasan Sadikin Bandung pada bulan Januari 2015-Juni 2016. Subjek penelitian sebanyak 21 orang dengan meningitis TB dilakukan pemeriksaan MRI kepala dengan kontras Gadolinium-DTPA. Analisis statistik komparatif dilakukan untuk menguji perbedaan peningkatan intensitas sinyal meningen sekuens T2-FLAIR post contrast dengan T1WI post contrast. Hasil penelitian menujukkan rerata peningkatan intensitas sinyal meningen sekuen T2-FLAIR ( $\Delta$ T2-FLAIR) sebesar 360,59 $\pm 182,19$ a $\mu$ sedangkan T1WI ( $\Delta$ T1WI) sebesar 126,47 $\pm 72,57$ a $\mu$. Hasil uji statistik menggunakan uji T pada derajat kepercayaan $95 \%$ menunjukkan perbedaan yang bermakna $\Delta \mathrm{T} 2$-FLAIR dengan $\Delta \mathrm{T} 1 \mathrm{WI}$ pada nilai $\mathrm{p}=0,000$. Sebagai simpulan didapatkan peningkatan intensitas sinyal meningen sekuens T2-FLAIR post contrast lebih besar daripada T1WI post contrast pada kasus meningitis TB. [MKB. 2017;49(3):172-77]
\end{abstract}

Kata kunci: Meningitis tuberkulosis, MRI sekuens T1WI dan T2-FLAIR, penyangatan meningeal

\section{Difference between Gadolinium-DTPA Enhanced T2 FLAIR Sequence and T1WI Sequence MRI in Detecting Meningeal Enhancement in Tuberculous Meningitis}

\begin{abstract}
The diagnosis of TB meningitis, especially in possible and probable cases, is difficult. Contrast-enhanced MRI of the head with Gadolinium-DTPA is the most sensitive imaging modality that supports diagnosis of this disease. The most common presentation of TB meningitis in MRI is basal meningeal enhancement. The objective of this study was to determine the difference in the increase of T2-FLAIR and T1WI sequence meningeal signal intensity of in patients with tuberculous meningitis using contrast-enhanced MRI of the head with Gadolinium-DTPA in Dr. Hasan Sadikin General Hospital from January 2015-June 2016. Contrast enhanced MRI examination was conducted in 21 subjects with TB meningitis. Statistical analysis was performed to examine the difference in the increase in meningeal signal intensity of post contrast T2-FLAIR and post contrast T1WI. The result showed that the mean increases in meningeal signal intensity of T2-FLAIR $(\Delta \mathrm{T} 2$-FLAIR) and T1WI $(\Delta \mathrm{T} 1 \mathrm{WI})$ were $360.59 \pm 182.19$ au and $126.47 \pm 72.57$ a $\mu$ respectively. Statistical test results using T test at $95 \%$ confidence level indicated that there was a difference between $\Delta \mathrm{T} 2$-FLAIR and $\Delta \mathrm{T} 1 \mathrm{WI}$ at $\mathrm{p}$-value $=0.000$. In conclusion, the mean increase in meningeal signal intensity of post contrast T2-FLAIR is greater than in the post contrast T1WI in TB meningitis. [MKB. 2017;49(3):172-77]
\end{abstract}

Key words: Meningeal enhancement, T1WI and T2-FLAIR sequence MRI, tuberculous meningitis

Korespondensi: Arie Hendarin, dr., Sp Rad., Rumah Sakit Umum Daerah Kabupaten Sumedang, Jalan Palasari No. 80, Kotakulon, Sumedang Selatan, Kabupaten Sumedang, Jawa Barat 45311,E-mail: ariehendarin@gmail.com 


\section{Pendahuluan}

Meningitis tuberkulosis atau meningitis TB merupakan salah satu bentuk dari penyakit TB pada sistem saraf pusat (SSP) yang paling banyak ditemukan. Penyakit ini ditandai dengan peradangan pada selaput otak (meningen) akibat infeksi kuman Mycobacterium tuberculosis yang berasal dari penyebaran hematogen dari infeksi TB di tempat lainnya (paling banyak dari TB paru). Meningitis TB menjadi penyebab kematian dan kecacatan terbesar no.7 di seluruh dunia. Penyakit ini menempati urutan ke-5 dari semua TB ekstra paru, memiliki angka kejadian $5,2 \%$ dari semua TB ekstraparu dan angka kejadian $0,7 \%$ dari semua kasus TB. Penyakit ini dapat menyerang semua kelompok usia dengan angka kejadian lebih banyak terjadi pada lakilaki daripada perempuan sebanyak dua banding satu. ${ }^{1}$

Diagnosis definitif meningitis TB hanya dapat ditegakkan dengan menemukan kuman TB di dalam cairan serebrospinal (CSS) baik menggunakan metode pewarnaan langsung, kultur, ataupun metode polymerase chain reaction (PCR). Pemeriksaan tersebut selain memakan waktu yang cukup lama juga jarang memberikan hasil yang positif. Angka sensitivitas metode pewarnaan langsung untuk menemukan basil tahan asam (BTA) kurang dari 20\% sementara dengan metode kultur 25-70\% dan dengan metode PCR adalah 56\%. Angka penemuan BTA pada pasien dewasa sebesar $80 \%$ dan pada anak hanya $15-20 \%$. Keberadaan TB aktif di organ lain hanya positif pada kurang dari 50\% kasus. Hal ini ditambah dengan gejala klinis meningitis TB seringkali tidak jelas sehingga penegakan diagnosis meningitis TB menjadi sulit. ${ }^{2-4}$

Marais dkk. ${ }^{5}$ telah membuat algoritma dan sistem skoring dalam menegakkan diagnosis meningitis TB. Menurut Marais dkk. ${ }^{5}$ pasien yang secara klinis mengarah pada kecurigaan meningitis TB dapat dibagi berdasar atas sistem skoring menjadi 4 kelompok, yaitu definite, probable, possible, dan bukan meningitis TB. Kriteria probable dan possible dapat ditegakkan tanpa harus menemukan BTA ataupun kuman TB. Kedua kriteria terakhir ini mencakup penilaian terhadap gambaran radiologi, khususnya pemeriksaan computed tomography (CT) dan magnetic resonance imaging (MRI) kepala. ${ }^{5,6}$

Gambaran CT dan juga MRI kepala yang menunjang ke arah diagnosis meningitis TB adalah ditemukannya penyangatan meningeal (meningeal enhancement) terutama di daerah basal setelah pemberian kontras, hidrosefalus, serta gambaran lesi iskemik terutama di daerah ganglia basalis. Penyangatan meningeal terutama di daerah basal merupakan gambaran yang paling sering ditemukan pada pemeriksaan CT dan MRI pada meningitis TB. Taheri dkk., ${ }^{10}$ menyatakan bahwa tanda ini merupakan gambaran CT dan MRI yang paling sensitif dan spesifik untuk meningitis TB., ${ }^{2,7}$

Pemeriksaan MRI kepala dengan kontras gadolinium-diethylene triaminepentaacetic acid (gadolinium-DTPA) memiliki sensitivitas yang lebih baik daripada CT kepala dengan kontras dalam mendeteksi keberadaan penyangatan meningeal pada meningitis TB (angka sensitivitas MRI 97\%, CT 70\%). Kelainan lain seperti lesi iskemik dan tuberkuloma juga lebih banyak terdeteksi dengan pemeriksaan MRI dibanding dengan CT. ${ }^{11-13}$

Sekuens MRI kepala yang dipergunakan juga ikut menentukan mendeteksi keberadaan penyangatan meningeal. Sekuens MRI kepala yang paling sering digunakan untuk mendeteksi keberadaan penyangatan meningeal adalah T1 weighted imaging dengan pemberian kontras gadolinium-DTPA (selanjutnya disebut T1WI post contrast). Sekarang ini, MRI kepala sekuens T2 fluid attenuated inversion recovery dengan pemberian kontras gadolinium-DTPA (selanjutnya disebut T2-FLAIR post contrast) banyak diteliti oleh para ahli untuk mendeteksi keberadaan penyangatan meningeal pada meningitis TB..$^{14,15}$

Pada penelitian yang telah dilakukan oleh Splendiani dkk. ${ }^{14}$ di Italia, Vaswani dkk. ${ }^{16} \mathrm{di}$ Pakistan, dan juga Parmar dkk. ${ }^{15}$ di Singapura menyatakan bahwa pemeriksaan MRI kepala pada pasien suspek meningitis dengan sekuens T2-FLAIR poskontras lebih sensitif dan spesifik daripada T1WI poskontras dalam mendeteksi keberadaan penyangatan meningeal tersebut. Penelitian yang dilakukan oleh Stuckey dkk. ${ }^{17}$ menyimpulkan bahwa penyangatan meningeal sekuens T2-FLAIR poskontras lebih jelas terlihat dibandingkan pada sekuens T1WI poskontras. Menurut Ahmad dkk. ${ }^{18}$ di India, penyangatan meningeal dapat diukur secara kuantitatifdengan memasang region of interrest (ROI) menggunakan perangkat lunak komputer tertentu di antaranya adalah RadiAnt DICOM Viewer for Windows. Ahmad dkk. ${ }^{18}$ menghitung kenaikan intensitas sinyal sekuens T2-FLAIR sebelum dan sesudah pemberian kontras gadolinium-DTPA, kemudian dibanding dengan kenaikan intensitas sinyal sekuens T1WI sebelum dan sesudah pemberian kontras gadolinium-DTPA. Ahmad dkk. ${ }^{18}$ telah menemukan bahwa kenaikan nilai rata-rata 
intensitas sinyal sekuens T2-FLAIR poskontras justru lebih rendah dibanding sekuens T1WI poskontras. ${ }^{14-18}$

Penelitian ini bertujuan mengetahui apakah terdapat perbedaan peningkatan intensitas sinyal meningen sekuens T2-FLAIR dengan T1WI pada pasien meningitis tuberkulosis menggunakan pemeriksaan MRI kepala dengan kontras gadolinium-DTPA di RSUP Dr. Hasan Sadikin Bandung. Penulis berharap bahwa hasil penelitian ini dapat memberikan manfaat terutama kepada para ahli radiologi untuk menentukan sekuens MRI yang paling optimal dalam mendeteksi keberadaan penyangatan meningeal pada kasus meningitis TB.

\section{Metode}

Penelitian ini ialah penelitian observasional analitik potong lintang yang berlangsung periode Januari 2015-Juni 2016 di RSUP Dr. Hasan Sadikin Bandung. Subjek penelitian terdiri atas 21 orang yang terdiagnosis sebagai meningitis TB (menggunakan kriteria Marais dkk. ${ }^{7}$ serta telah memenuhi kriteria inklusi dan tidak termasuk eksklusi yang sudah ditetapkan. Pengambilan sampel dilakukan secara consecutive sampling (sambil dinilai berdasar kriteria inklusi dan eksklusi yang dapat dilihat pada Tabel 1) sampai jumlah sampel minimal terpenuhi.

Pemeriksaan MRI kepala dilakukan dengan mesin MRI Magnetom Essenza 1,5 Tesla dari Siemens. Coil yang digunakan adalah coil khusus untuk kepala. Parameter untuk sekuens T1WI pre dan poskontras adalah TR 450 milidetik, TE 10 milidetik, slice thickness $5 \mathrm{~mm}$, interslice gap 1,5 $\mathrm{mm}$, FOV $230 \mathrm{~mm}$. Waktu pengambilan sekuens T1WI pre dan poskontras masing-masing adalah selama 2 menit 59 detik. Parameter untuk sekuens T2-FLAIR pre dan poskontras adalah TR 9.000 milidetik, TE 87 milidetik, TI 2.500 milidetik, slice thickness $5 \mathrm{~mm}$, interslice gap 1,5 $\mathrm{mm}$, FOV $230 \mathrm{~mm}$. Waktu pengambilan sekuens T2-FLAIR pre dan poskontras masing-masing adalah selama 3 menit 38 detik. Dosis pemberian kontras gadolinium-DTPA intravena adalah sebanyak 0,2 mL/kgBB. Sekuens T2-FLAIR poskontras dilakukan langsung setelah sekuens T1WI poskontras selesai.

Nilai intensitas sinyal didapatkan dengan cara memasang ROI di lokasi yang secara kualitatif terlihat ada penyangatan meningeal (umumnya di daerah sisterna basalis dan ambien). Lokasi dan ukuran ROI dibuat sama untuk semua sekuens agar dapat dibandingkan. Ukuran ROI dibuat sedemikian rupa sehingga hanya mencakup struktur meningen. Perangkat lunak komputer yang digunakan untuk membuat ROI dalam penelitian ini adalah RadiAnt DICOM Viewer for Windows versi 3.2.2 64 bit.

Nilai intensitas sinyal untuk sekuens T2FLAIR pre dan poskontras serta T1WI pre dan post contrast dari semua pasien diambil. Variabel $\Delta$ T2-FLAIR didapatkan dengan cara mengurangi nilai intensitas sinyal T2-FLAIR poskontras dengan poskontras. Variabel $\Delta \mathrm{T} 1 \mathrm{WI}$ didapatkan dengan cara mengurangi nilai intensitas sinyal T1WI poskontras dengan prekontras.

Uji normalitas Shapiro Wilk terhadap variabel $\Delta T 2$-FLAIR dan $\Delta$ T1WI semua subjek penelitian dilakukan untuk dapat mengetahui apakah data berdistribusi normal atau tidak. Jika nilai $p>0,05$ maka data berdistribusi normal namun jika nilai $\mathrm{p} \leq 0,05$ maka data tidak berdistribusi normal.

Uji analitik komparatif dilakukan untuk menguji perbedaan nilai $\Delta$ T2-FLAIR dengan $\Delta$ T1WI rata-rata. Apabila data berdistribusi normal maka pengujian dilakukan menggunakan uji $\mathrm{T}$ untuk dua kelompok data berpasangan,

\section{Tabel 1 Kriteria Inklusi dan Eksklusi}

\begin{tabular}{|c|c|}
\hline Kriteria Inklusi & Kriteria Eksklusi \\
\hline $\begin{array}{l}\text { - Subjek yang datang ke poliklinik saraf atau instalasi } \\
\text { gawat darurat RSUP Dr. Hasan Sadikin Bandung } \\
\text { yang pada pemeriksaan klinis dan laboratorium } \\
\text { termasuk ke dalam kriteria possible, probable, atau } \\
\text { definite meningitis TB. } \\
\text { Subjek kooperatif sehingga pada gambar MRI } \\
\text { kepala terdapat gambaran motion artefact. }\end{array}$ & $\begin{array}{ll}\text { - } & \text { Subjek memiliki kontraindikasi terhadap } \\
\text { pemeriksaan MRI kepala dengan kontras } \\
\text { gadolinium-DTPA } \\
\text { - Subjek menderita penyakit atau memiliki } \\
\text { riwayat penyakit keganasan baik di otak } \\
\text { ataupun organ lainnya. } \\
\text { - Subjek menderita penyakit perdarahan } \\
\text { subaraknoid. } \\
\text { - Subjek pernah mendapatkan injeksi kontras } \\
\text { gadolinium-DTPA atau iodium dalam waktu } 7 \\
\text { hari sebelumnya. }\end{array}$ \\
\hline
\end{tabular}


sedangkan jika data tidak berdistribusi normal maka pengujian dilakukan dengan uji Wilcoxon. Semua analisis dan pengolahan data dilakukan menggunakan program statistical Product and Service Solution (SPSS) for windows versi 22.0 pada derajat kepercayaan $95 \%$.

\section{Hasil}

Subjek penelitian sebanyak 21 orang terdiri atas laki-laki 12 orang dan perempuan 9 orang. Usia subjek penelitian berkisar antara 16 tahun sampai 57 tahun (usia rata-rata 32,86 $\pm 12,95$ tahun) dengan kelompok usia terbanyak pada usia 25-34 tahun sebanyak 8 orang. Subjek lakilaki sebanyak 12 orang berusia $24,22,40,49,47$, $34,26,34,56,31,29$, dan 31 tahun sedangkan subjek perempuan sebanyak 9 orang berusia 20 , $52,18,33,17,16,20,57$, dan 34 tahun.

Gambar pemeriksaan MRI dan pemasangan ROI salah satu subjek penelitian dapat dilihat pada Gambar 1. Hasil MRI beserta nilai intensitas sinyal sekuens T1WI pre dan poskontras, T2FLAIR pre dan poskontras, $\triangle \mathrm{T} 1 \mathrm{WI}$ dan $\Delta \mathrm{T} 2$ FLAIR beserta hasil uji normalitasnya dapat dilihat pada Tabel 3. Hasil uji normalitas menggunakan uji Shapiro Wilk menunjukkan hasil bahwa baik variabel $\Delta$ T2-FLAIR maupun $\Delta$ T1WI berdistribusi normal $(\mathrm{p}>0,05)$.

Tabel 2 menunjukkan nilai rata-rata $\Delta \mathrm{T} 2$ FLAIR $(360,59 \pm 182,19)$ lebih besar daripada $\Delta$ T1WI $(126,47 \pm 72,57)$. Hasil analisis statistik menggunakan uji $\mathrm{T}$ pada derajat kepercayaan 95\% (Tabel 3) memberikan nilai $\mathrm{p}=0,000$ yang menunjukkan perbedaan bermakna antara $\Delta \mathrm{T} 2$ -
FLAIR dan $\Delta$ T1WI.

\section{Pembahasan}

Menurut literatur, peningkatan intensitas sinyal meningen antara sekuens MRI sebelum dan setelah pemberian kontras gadolinium-DTPA menunjukkan penyengatan meningeal di daerah tersebut. Hasil penelitian ini menunjukkan bahwa pada pemeriksaan MRI kepala dengan kontras Gadolinium-DTPA terhadap 21 subjek penelitian, sekuens T2-FLAIR poskontras yang memberikan penyangatan meningeal yang lebih tinggi daripada sekuens T1WI poskontras. Dengan kata lain, penyangatan meningeal pada meningitis TB lebih jelas terlihat pada sekuens T2-FLAIR poskontras daripada sekuens T1WI post contrast. Keadaan ini sejalan dengan hasil penelitian Splendiani dkk. ${ }^{14}$, Vaswani dkk., ${ }^{16}$ dan Parmar dkk. ${ }^{15}$ yang menyebutkan bahwa sekuens T2-FLAIR poskontras memberikan penyangatan meningeal yang lebih tinggi daripada sekuens T1WI poskontras sehingga sekuens T2-FLAIR post contrast lebih sensitif dan spesifik daripada sekuens T1WI poskontras dalam mendeteksi keberadaan penyangatan meningeal pada kasus meningitis. ${ }^{14-16,18}$

Ada beberapa landasan teori yang mendukung hasil di atas. Pertama, aliran darah lambat pada vaskular terutama pada vena subaraknoid umumnya memberikan sinyal hiperintens pada sekuens T1WI pre dan poskontras. Hal ini akan mengganggu gambaran hiperintensitas dari penyangatan meningeal ketika terjadi reaksi inflamasi di daerah tersebut. Pada sekuens T2-

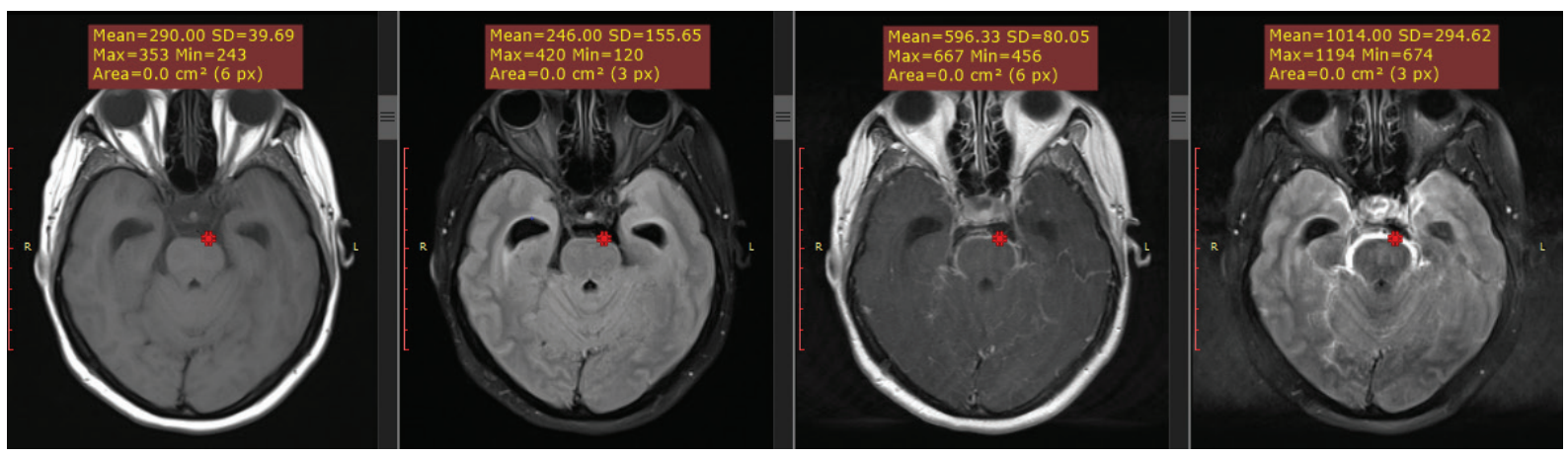

Gambar Hasil MRI Salah Satu Subjek Penelitian

MRI sekuens T1WI prekontras (A), T2-FLAIR prekontras (B), T1WI poskontras(C) dan T2-FLAIR poskontras (D). Terlihat penyangatan meningeal di daerah sisterna prepontine. Penyangatan meningeal sekuens T2FLAIR poskontras terlihat lebih jelas dibanding dengan sekuens T1WI poskontras. Nilai $\Delta$ T2-FLAIR-pun lebih besar daripada $\Delta$ T1WI-nya. 
Tabel 3 Hasil MRI

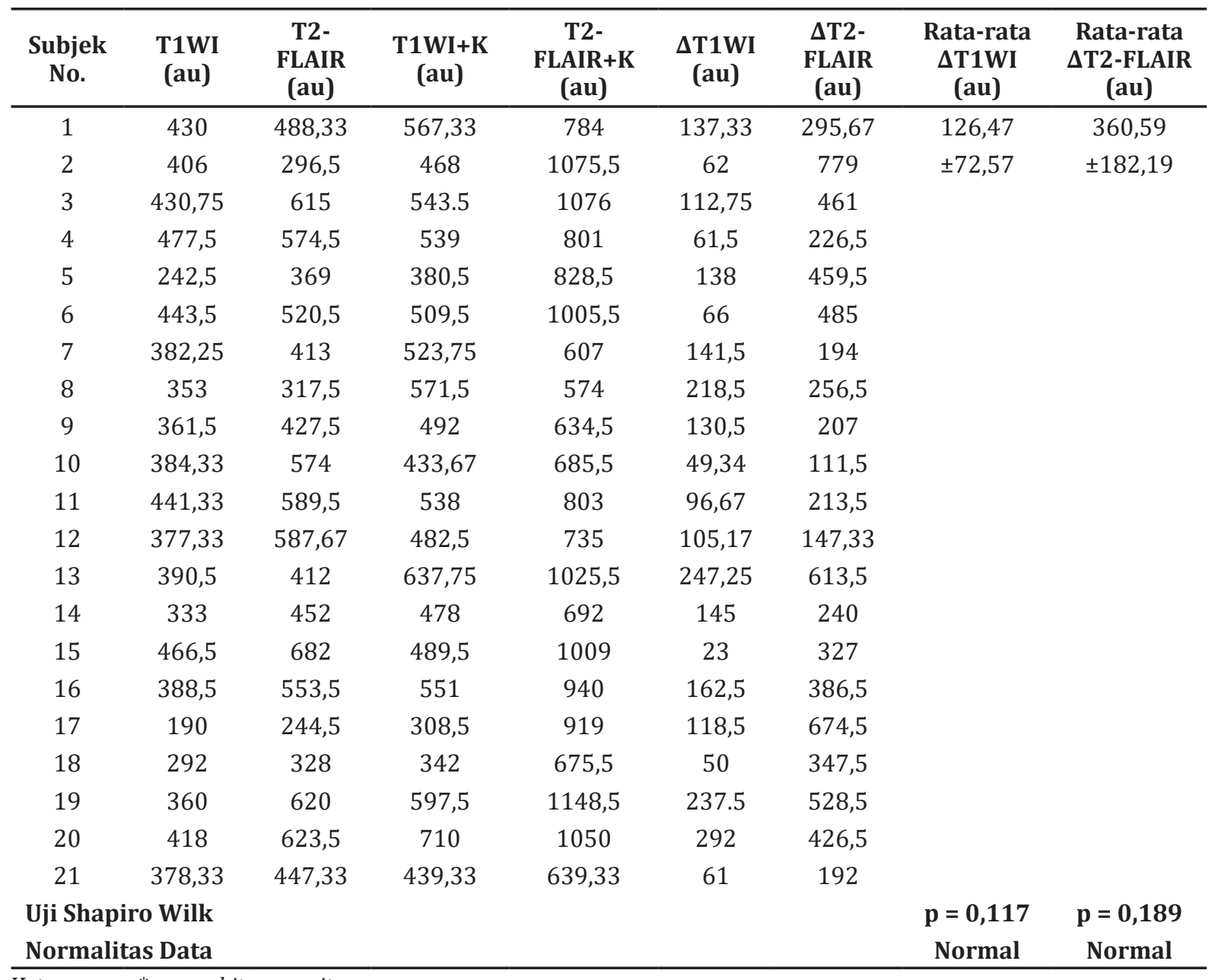

Keterangan: * au : arbitrary unit

FLAIR pre dan poskontras, hal tersebut tidak akan terjadi karena sekuens ini mampu menekan sinyal yang berasal dari vaskular sehingga ketika terjadi penyangatan meningeal akibat inflamasi, gambaran hiperintensitas dari penyangatan meningeal ini akan lebih jelas terlihat. Kedua, menurut salah satu penelitian dinyatakan bahwa efek penyangatan dari kontras gadolinium-DTPA suatu struktur sudah dapat terdeteksi pada sekuens T2-FLAIR poskontras pada konsentrasi gadolinium-DTPA yang lebih rendah dibanding dengan konsentrasi Gadolinium-DTPA pada sekuens T1WI poskontras sehingga dengan konsentrasi Gadolinium-DTPA yang sama maka penyangatan pada T2-FLAIR poskontras itu akan lebih jelas terlihat daripada T1WI poskontras. ${ }^{17,19,20}$

Sebagai simpulan, penyangatan meningeal pada meningitis TB lebih jelas terlihat pada sekuens T2-FLAIR poskontras daripada sekuens T1WI poskontras. Penulis menyarankan agar diadakan penelitian lebih lanjut mengenai hal ini (misalnya menilai sensitivitas dan spesifisitas MRI T2 FLAIR poskontras khusus untuk populasi

Tabel 4 Uji T Variabel $\Delta T 2$-FLAIR dan $\Delta T 1 W I$

\begin{tabular}{llll}
\hline \multirow{2}{*}{ Variabel } & \multicolumn{2}{c}{ Sekuens } & Nilai p \\
\cline { 2 - 3 } & \multicolumn{1}{c}{$\Delta$ T2-FLAIR } & \\
\cline { 2 - 3 } Kenaikan intensitas sinyal & & & \\
\cline { 2 - 3 } Rata-rata & $360,59 \pm 182,19 \mathrm{a} \mu$ & $126,47 \pm 72,57 \mathrm{a} \mu$ & 0,000 \\
\hline
\end{tabular}


TB meningitis di Indonesia sehingga diharapkan T2-FLAIR poskontras ini menjadi salah satu sekuens tambahan dalam protokol pemeriksaan MRI kepala pada kasus dengan suspek meningitis TB agar deteksi dan diagnosis dini penyakit ini dapat lebih cepat dilakukan.

\section{Daftar Pustaka}

1. Ramachandran TS. Tuberculous meningitis. 2014 [diunduh 21 Maret 2016]. Tersedia dari: http://emedicine.medscape.com/ article/1166190-overview\#a5.

2. Sher K, Firdaus, Abbasi A, Bullo N, Kumar S. Stages of tuberculous meningitis: a clinicoradiologic analysis. J College Physcians Surg Pakistan. 2013;23(6):405-8

3. Thwaites G, Fisher M, Hemingway C, Scott G, Solomon T, Innes J. British infection society guidelines for the diagnosis and treatment of tuberculosis of the central nervous system in adults and children. J Infect. 2009;59:16787.

4. Marx GE, Chan ED. Tuberculous meningitis: diagnosis and treatment overview. Tuberc Res Treat. 2011;2011:798764.

5. Marais S, Thwaites G, Schoeman JF, Torok ME, Misra UK, Prasad K, dkk. Tuberculous meningitis: a uniform case definition for use in clinical research. Lancet Infect Dis. 2010;10(11):803-12.

6. Solomons RS, Wessels M, Visser DH, Donald PR, Marais BJ, Schoeman JF, dkk. Uniform research case definition criteria differentiate tuberculous and bacterial meningitis in children. Clin Infect Dis. 2014;59(11):15748.

7. Bathla G, Khandelwal G, Maller VG, Gupta A. Manifestations of cerebral tuberculosis. Singapore Med J. 2015;52(2):124-30;31.

8. Przybojewski S, Andronikou S, Wilmshurst J. Objective CT criteria to determine the presence of abnormal basal enhancement in children with suspected tuberculous meningitis. Pediatr Radiol. 2006;36(7):68796.

9. Chin JH. Tuberculous meningitis: diagnostic and therapeutic challenges. neurol clin pract. 2014;4(3):199-205.
10. Taheri MS, Karimi MA, Haghighatkhah H, Pourghorban R, Samadian M, Kasmaei HD. Central nervous system tuberculosis: an imaging-focused review of a reemerging disease. Radiol Res Pract. 2015;2015:202806.

11. Pienaar M, Andronikou S, van Toorn R. MRI to demonstrate diagnostic features and complications of TBM not seen with CT. Childs Nerv Syst.25(8):941-7.

12. Morgado C, Ruivo N. Imaging meningoencephalic tuberculosis. Eur J Radiol. 2005; 55(2):188-92.

13. Burrill J, Williams CJ, Bain G, Conder G, Hine $\mathrm{AL}$, Misra RR. Tuberculosis: a radiologic review. Radiographics. 2007;27(5):1255-73.

14. Splendiani A, Puglielli E, De Amicis R, Necozione S, Masciocchi C, Gallucci M. Contrast-enhanced flair in the early diagnosis of infectious meningitis. Neuroradiology. 2005;47(8):591-8.

15. Parmar H, Sitoh YY, Anand P, Chua V, Hui F. Contrast-enhanced flair imaging in the evaluation of infectious leptomeningeal diseases. Eur J Radiol. 2006;58(1):89-95.

16. Vaswani AK, Nizamani WM, Ali M, Aneel G, Shahani BK, Hussain S. Diagnostic accuracy of contrast-enhanced flair magnetic resonance imaging in diagnosis of meningitis correlated with CSF analysis. ISRN Radiol. 2014;2014:578986.

17. Stuckey SL, Goh TD, Heffernan T, Rowan D. Hyperintensity in the subarachnoid space on flair MRI. AJR Am J Roentgenol. 2007;189(4):913-21.

18. Ahmad A, Azad S, Azad R. Differentiation of leptomeningeal and vascular enhancement on post-contrast flair MRI sequence: role in early detection of infectious meningitis. J Clin Diagn Res. 2015;9(1):TC08-12.

19. Lee EK, Lee EJ, Kim S, Lee YS. Importance of contrast-enhanced fluid-attenuated inversion recovery magnetic resonance imaging in various intracranial pathologic conditions. Korean J Radiol. 2016;17(1):12741.

20. Absinta M, Vuolo L, Rao A, Nair G, Sati P, Cortese IC, dkk. Gadolinium-based MRI characterization of leptomeningeal inflammation in multiple sclerosis. Neurology. 2015;85(1):18-28. 